\title{
Teachers' Awareness of Second Language Learning Strategies Adopted and Used by Their Students: A Questionnaire
}

\author{
Ahmed Qadoury Abed \\ Translation Department, College of Arts, Al-Mustansiriyah University, Iraq \\ Email: Ahmed_121204@yahoo.com
}

\begin{abstract}
The present study investigates Iraqi university-level teachers' awareness of these strategies adopted and used by their students in leaning a second language. A questionnaire is administered to twenty-seven teachers in five department regarding English as their major knowledge. Definitions, importance classifications and teaching second language learning strategies are dealt with. The study shows that these teachers are aware that their students are able to adopt and use a number of these strategies more proficiently than others .Aware and unaware strategies can be regarded as points of strength and weakness, respectively, if a strategy-based instruction is applied inside the classroom. Iraqi university-teachers are aware of these strategies used and adopted by their students inside the classroom. Meta-cognitive strategies are more adopted and used by students; therefore the less problematic one. Whereas Affective strategies are more problematic than other types of strategies. English academic majors, i.e., linguistics, literature, and translation proved to be effective in students' use of strategies.
\end{abstract}

Index Terms - second language learning strategies, Iraqi EFL learners, SILL

\section{INTRODUCTION}

There has been a great shift within the field of language learning and teaching over the last decades with a lot of emphasis put on learners and learning rather than on teachers and teaching. This change has been reflected in various ways in language education and applied linguistics: in parallel to this new shift of interest, how learners process new information, what kinds of strategies they use to understand, learn, or remember the information has been the primary concern of researchers tackling the area of second language learning strategies (abbreviated as SLLSs).

Researchers in the field of language and linguistics used a number of definitions. On early research, Tarone (1983) presented the following definition of language strategy (abbreviated as LS) as an "attempt to develop linguistic and sociolinguistic competence in the target language - to incorporate to the development of the language system which the learner constructs and affect learning directly" (p. 87). While Weinstein \& Mayer (1986) considered these strategies broadly as "behaviours and thoughts that a learner engages in during learning" which are "intended to influence the learner's encoding process" (p.351). Later, Mayer (1988) more specifically believed that LS are "behaviours of a learner that are intended to influence how the learner processes information" (p. 11). According to Wenden \& Rubin (1987, p. 19), LSs are “... any sets of operations, steps, plans, routines used by the learner to facilitate the obtaining, storage, retrieval, and use of information”. In their seminal study, O’Malley and Chamot (1990, p. 1) adopted the following definition of LS as "the special thoughts or behaviours that individuals use to help them comprehend, learn, or retain new information". According to Stern (1992, p. 261), "the concept of learning strategy is dependent on the assumption that learners consciously engage in activities to achieve certain goals and learning strategies can be regarded as broadly conceived intentional directions and learning techniques." All language learners use SLLSs either consciously or unconsciously when processing new information and performing tasks in the language classroom. Since the classroom is like a problem-solving environment in which language learners are likely to encounter new input and difficult tasks given by their instructors, learners' attempts to find the fastest or easiest way to do what is required, that is, using SLLSs is impossible to avoid. Finally, building on the work in her outstanding book for teachers Language Learning Strategies: What Every Teacher Should Know (1990), and affirmed in (1993, p. 18), Rebecca Oxford gives a specific definition:

...language learning strategies-(are) specific actions, behaviours, steps, or techniques that students (often intentionally) use to improve their progress in developing L2 skills. These strategies can facilitate the internalization, storage, retrieval, or use of the new language Strategies are tools for the self-directed involvement necessary for developing communicative ability.

We may note a change over time from these definitions: from the early focus on the product of SLLSs (linguistic or sociolinguistic competence), there is now a larger emphasis on the processes and the characteristics of SLLSs. At the same time, we should note that SLLSs are distinct from learning styles, which refer more broadly to a learner's "natural, habitual, and preferred way(s) of absorbing, processing, and retaining new information and skills" (Reid, 1995, p. viii). 
Although there appears to be an obvious relationship between one's language learning style and his or her usual or preferred language learning strategies. This paper provides the background of SLLSs, presents different definitions and classifications of these strategies given by many researchers. It also emphasizes the importance of SLLSs for foreign language learning and teaching. A questionnaire will be done to present a clear portrait of these SLLSs held by Iraqi students of English indirectly by asking their teachers to answer the questionnaire paper. A statistical analysis and discussion of the results are also done.

\section{IMPORTANCE OF SLLSS}

The Communicative Approach in language teaching starts from a theory of language as communication. The key goal of language teaching is to develop what Hymes (1972) referred to as communicative competence in the target language. These strategies can help learners develop this competence. A number of works appeared about communicative strategies in target language (abbreviated as TL) after Canale and Swain's (1994) influential article recognized the importance of communicative strategies as a key aspect of strategic (and thus communicative) competence. An essential distinction exists, however, between communication and SLLSs. Communicative strategies are used by speakers intentionally and consciously in order to cope with difficulties in communicating in a TL (Cook,2001, p.211-224)). This term "Language Learning Strategies" is used more generally for all strategies that L2/FL learners use in learning the target language, and communication strategies are therefore just one type of SLLSs. Therefore, understanding of SLLSs is very crucial for all L2 teachers' who aim to help develop their students' communicative competence and language learning. As Oxford (1990, p.1) puts it, SLLSs “... are especially important for language learning because they are tools for active, self-directed involvement, which is important for developing communicative competence." Lessard-Clouston (1997, p.3) points out that SLLSs add to the development of the communicative competence of the students. Being abroad concept, used to refer to all strategies used by foreign language learners in learning the TL and communication strategies are one type of Learning Strategies.

Second Language learning strategies are important, in addition to developing students' communicative competence because research suggests that training students to use these strategies can help them become better learners. Early research on 'good language learners' by Naiman, Frohlich, Stern, and Todesco (1978, 1996), Rubin (1975), and Stern (1975) suggested a number of positive strategies that such students employ, ranging from using an active task approach in and monitoring one's L2 / FL performance to listening to the radio in L2/FL and speaking with native speakers (see Ellis,1994,ch.7). A study by O'Malley and Chamot (1990) also suggests that effective L2/FL learners are aware of the SLLSs they use and why they use them. According to Ellis (ibid., p.258), the language learner who is able to use a wide variety of SLLSs can improve his language skills in a better way.

There is a caution which we must note though, because, as Skehan (1989, p.76) remarks, "there is always the possibility that the 'good' language learning strategies... are also used by bad language learners, but other reasons cause them to be unsuccessful learners." In fact, Vann \& Abraham (1990:192) found evidence which suggests that both 'good' and 'unsuccessful' language learners "apparently...lacked... what are often called meta-cognitive strategies...which would enable them to assess the task and bring to bear the necessary strategies for its completion". It seems, then, that a number and range of SLLSs are necessary if L2/FL teachers are to help students both in learning the L2/FL and in becoming successful language learners. At this point, it should highly emphasized that the use of the same good SLLSs does not guarantee that bad learners will also become successful in language learning since other factors may also play role in their success.

\section{CLASSIFICATION OF SLLSS}

These strategies are classified by many scholars like, O’Malley et al. (1985), Wenden \& Rubin (1987); Stern (1992); Oxford (2001) etc. However, most of these endeavours to classify language learning strategies reflect more or less the same categories of language learning strategies without any radical changes. In what follows, these taxonomies of language learning strategies will be dealt with:

\section{A. O'Malley's (1985) Classification}

O’Malley et al. (1985, p.582-84) categorize SLLSs into three main subcategories:

Meta-cognitive Strategies

Cognitive Strategies

Socio-affective Strategies

1. Meta-cognitive Strategies

It can be pointed out that meta-cognitive is a term used to express executive function; strategies which require planning for learning, thinking about the learning process as it is taking place, monitoring of one's production or comprehension, and evaluating learning after an activity is completed. Among the main meta-cognitive strategies, it is possible to include advance organizers, directed attention, selective attention, self-management, functional planning, self-monitoring, delayed production, and self-evaluation.

2. Cognitive Strategies 
These strategies are more limited to specific tasks. They involve direct manipulation of the learning material itself. Repetition, resourcing, translation, grouping, deduction, imagery, key word, note-taking, recombination, auditory representation, elaboration inferencing, contextualization and transfer are among the most essential cognitive strategies.

3. Socioaffective Strategies

As Brown (2000, p. 93-94) states, socio-affective strategies relate with social-mediating activity and transacting with others. Cooperation and question for clarification are the major socio-affective strategies.

\section{B. Rubin's (1987) Classification}

Rubin makes the distinction between strategies contributing directly to learning and those contributing indirectly to learning. He states three types of strategies used by learners. These are:

Learning Strategies

Communication Strategies

Social Strategies

1. Learning Strategies

These strategies fall into two main types. They contribute directly to the development of the language system constructed by the learner:

a. Cognitive Learning Strategies; they refer to the steps or operations used in learning or problem solving that requires direct analysis, transformation, or synthesis of learning materials. Rubin identified six main cognitive strategies contributing directly to language learning:

a). Clarification/ Verification

b). Deductive Reasoning

c). Guessing/ Inductive Inferencing

d). Practice

e). Memorization

f). Monitoring

b. Meta-cognitive Learning Strategies; these strategies are used to self-direct or regulate, oversee language learning. They include various processes as planning, prioritizing, setting goals, and self-management.

2. Communicative strategies

Communication strategies less relate to language learning since their focus is on the process of participating in a conversation and getting meaning across or clarifying what the speaker intended. They are used by speakers when met with some difficulties due to the fact that their communication ends outrun their communication means or when confronted with misunderstanding by a co-speaker (see also Ellis, 2005, p. 170-173).

3. Social Strategies

They are the type of activities learners engage in which afford them opportunities to be exposed to and practice their knowledge. According to Wenden \& Rubin (1987, p. 23-27), these strategies contribute indirectly to learning although they provide exposure to the TL because they do not lead directly to the obtaining, storing, retrieving, and using of language.

\section{Stern's (1992) Classification}

There are five main SLLSs according to Stern (1992:262-66). They are as follows:

Management and Planning Strategies

Cognitive strategies

Communicative-Experiential Strategies

Interpersonal Strategies

Affective Strategies

1. Management and Planning Strategies

These strategies relate with the learner's attention to direct his own learning. A learner can take charge of the development of his own programme when he is helped by a teacher whose role is to say that the learner must:

a. set himself reasonable goals.

b. decide on an appropriate methodology, select appropriate resources, and monitor progress

c. decide what commitment to make language learning,

d. evaluate his achievement in the right of previously determined goals and expectations (ibid.,p. 263).

2. Cognitive strategies

These are operations used in learning or problem solving which need direct analysis, transformation, or synthesis of learning materials. Here, some of the cognitive strategies listed:
a. Clarification
b. Deductive Reasoning
c. Guessing / Inductive Inferencing
d. Memorization
e. Practice
f. Monitoring 


\section{Communicative-Experiential Strategies}

As stated by Stern (ibid.) communication strategies like gesturing, circumlocution, paraphrase, explanation, or asking for repetition are techniques learners use them to continue a conversation. The aim of using these techniques is to avoid interrupting the flow of communication.

4. Interpersonal Strategies

Learners should contact with native speakers and cooperate with them. In addition, they should monitor their own development and evaluate performance their own performance. They must become acquainted with the target culture (ibid.).

\section{Affective Strategies}

Stern (ibid) puts it that good language learners use distinct affective strategies. Because of the nature of language learning which is in some cases frustrating, L2 learners may have negative feelings about native speakers of L2. Good language learners are more or less conscious of these emotional problems, so they try to create associations of positive effect towards the foreign language and its speakers as well the learning activities involved. Learning training can help students to face up to the emotional difficulties and to overcome them by drawing attention to the potential frustrations or pointing them out as they arise.

\section{Oxford's (2001) Classification}

The aim of SLLSs as viewed by Oxford (2001) is the orientation towards the development of communicative competence. She classifies these strategies into two main divisions, direct and indirect, which are further sub-classified into six categories. In Oxford's system, meta-cognitive strategies help learners to regulate their learning. Affective strategies are concerned with the learner's emotional requirements such as confidence, while social strategies lead to increased interaction with the target language (TL). Cognitive strategies are the mental strategies learners use to make sense of their learning, memory strategies are those used for storage of information, and compensation strategies help learners to overcome knowledge gaps to continue the communication. Oxford (2001, p. 359) presents six categories of language learning strategies: cognitive, meta-cognitive, memory-related, compensatory, affective, and social. They can be summarized as follows:

1. Cognitive: practicing and repeating new words; deductive reasoning, translating, analyzing; taking notes, highlighting, summarizing.

2. Meta-cognitive: paying attention, organizing, setting goals, and objectives, evaluating one's own performance.

3. Memory-related: creating mental linkages, such as grouping and placing words in context; applying images and sounds to represent things in memory; structured reviewing; using mechanical techniques, such as physical response.

4. Compensatory: selecting a topic for discussion based on one's knowledge of the language and shaping the discussion to avoid unknown vocabulary, guessing at words based on context, using gestures and coining words to communicate.

5. Affective: using music or laughter as part of the learning process, rewording oneself, making positive statements about one's own progress, discussing feelings.

6. Social: seeking correction, asking for clarification, working with peers, developing cultural understanding (ibid. ,p. 363-365).

Some strategies are guided by exterior influences: teachers, activities, interactions-and others relate to the student's personality, motivation, and knowledge about how to learn.

We can notice that much of the recent work in this area has underpinned by a broad concept of SLLSs that goes beyond cognitive processes to include social and communicative strategies.

\section{TEACHING SLLSS}

The teacher's role in strategy training is very important. Therefore training students on how to use SLLSs, teachers should learn about their students' interests, motivations and learning styles. The teacher can learn what SLLSs his/her students appear to be using by observing their behaviour in class: do they cooperate with their peers or seem to have much contact outside of class with proficient foreign language users? Do they ask for clarification, verification or correction? In addition to that, the teacher can have adequate knowledge about his/her students' goals, motivations, language learning strategies, and their understanding of the course to be taught (Lessard-Clouston 1997, 5). It is true that each learner within the same classroom may have different learning styles and varied awareness of the use of strategies. The teacher cannot ascribe importance to only one group and support the analytical approach or only give input by using the auditory mode. Therefore, the language teacher should provide a wide range of learning strategies in order to meet the needs and expectations of his students processing different learning styles, motivations, strategy preferences, etc. It can be pointed out that the most important teacher's role in foreign language teaching is the provision of a range of tasks to match varied learning styles.

In addition to students, language teachers should also analyze the textbooks to find out whether the textbooks already include SLLSs or SLLSs training. They should look for new texts or other teaching materials if SLLSs are not already included within their materials.

Language teachers should also study their own teaching methods and overall classroom style. Moreover, they should 
analyze their lesson plans, and can determine whether their lesson plans give learners an opportunity to employ a variety of learning styles and learning strategies or not. Furthermore, teachers can see whether their teaching allows learners to approach the task at hand in different ways or not. Again, language teachers can also be aware of whether their strategy training is implicit, explicit or both. It should be stressed that questioning themselves about what they plan to do before each lesson and evaluate their lesson plans after the lesson. In terms of strategy training, teachers can become better prepared to concentrate on language learning strategies and strategy training during the process of their teaching, and can encourage their students to experiment with abroad range of strategies after of course, describe, model, and give examples of potentially useful strategies (Lessard-Clouston 1997: ibid).

Strategies, like styles, can be taught, and because of their specificity, even more easily than style (Brown, 2001, 217). At least four approaches are applicable:

1- Teach strategies through interactive techniques.

2- Use compensatory techniques.

3- Administer a strategy inventory.

4- Make use of impromptus teacher - initiated advice.

Linguists, like Oxford (2001), believe that the first and third approaches are more usable than the other two since applying them is easier, with reference to the cooperation between teachers and their students is very considerable(p.361).

Considerable research has been conducted on how to improve L2 students' learning strategies. In many investigations, attempts to teach students to use learning strategies (called strategy training or learner training) have produced good results. However, not all L2 strategy training studies have been successful or conclusive. Some training has been effective in various skill areas but not in others, even within the same study. Based on L2 strategy training research, the following principles have been tentatively suggested, subject to further investigation (see Oxford (1994) and Yang (2007, p.36ff)):

- L2 strategy training should be based clearly on students' attitudes, beliefs, and stated needs.

- Strategies should be chosen so that they mesh with and support each other and so that they fit the requirements of the language task, the learners' goals, and the learners' style of learning.

- Training should, if possible, be integrated into regular L2 activities over a long period of time rather than taught as a separate, short intervention.

- Students should have plenty of opportunities for strategy training during language classes.

- Strategy training should include explanations, handouts, activities, brainstorming, and materials for reference and home study.

- Affective issues such as anxiety, motivation, beliefs, and interests -- all of which influence strategy choice -should be directly addressed by L2 strategy training.

- Strategy training should be explicit, overt, and relevant and should provide plenty of practice with varied L2 tasks involving authentic materials.

- Strategy training should not be solely tied to the class at hand; it should provide strategies that are transferable to future language tasks beyond a given class.

- Strategy training should be somewhat individualized, as different students prefer or need certain strategies for particular tasks.

Strategy training should provide students with a mechanism to evaluate their own progress and to evaluate the success of the training and the value of the strategies in multiple tasks

\section{A QUeSTIONNAIRE}

A questionnaire is administered to identify university - level teachers of English's awareness of these SLLSs adopted by their students in learning English as a second language. This questionnaire is based on Oxford's Strategy Inventory for Language Learning (abbreviated as SILL), version 7.0, cited completely in Brown (ibid., p. 221ff). Two basic changes are made on this inventory to be suitable for the present study. Firstly, the number of options has been decreased from five (never, usually not, somewhat, usually yes, always) to three only (never, sometimes, always), since the other two options may mislead the subjects of the study as stated by the pilot administration of the questionnaire, especially in Wassit University, College of Education, Department of English in May 2008. Secondly, the fifty strategies have been reworded in a way to be easily- understood. This rewording was given to a number of experts in applied linguistics, all of them holding the academic rank Assistant Professor, to judge the changes till the final version was reached. The same classification of these fifty strategies into six categories (see sect. 3.4 above) was adopted without mentioning this fact to the subjects.

Forty university-level teachers of English were the subject of the questionnaire. Unfortunately, only twenty- seven were accepted since the other thirteen questionnaire papers were rejected for more than one reason: some returned the questionnaire paper with no response (i.e., empty), some were half- answered, and the others with ticking the all three options. Therefore, the following two tables show the details of the subjects of the present study: 
TABLE (1):

WORK DETAILS AND DEGREES OF THE STUDY SUBJECTS

\begin{tabular}{|c|c|c|c|c|}
\hline \multirow[b]{2}{*}{ University/College/Dept. } & \multicolumn{2}{|c|}{ MA } & \multicolumn{2}{|c|}{ PH D } \\
\hline & Male & Female & Male & Female \\
\hline Wassit/Education/English & 3 & 3 & & \\
\hline Baghdad/Languages/English & & & 1 & \\
\hline Baghdad/Arts/English & 4 & 4 & & 1 \\
\hline Mustansiriyah/Arts/English & & 2 & & \\
\hline Mustansiriyah/Arts/Translation & 3 & 2 & 3 & 1 \\
\hline Total & & & & \\
\hline
\end{tabular}

This table indicates that five departments were contributed in this study. The number of subjects indicates in one way or another the range of sincere cooperation seen while the questionnaire papers were submitted to the forty- subjects.

TABLE (2):

THE SUBJECTS AND THEIR FIELDS OF KNOWLEDGE

\begin{tabular}{|c|c|c|c|c|}
\hline \multirow{3}{*}{ Field } & \multicolumn{4}{|c|}{ Degree } \\
\hline & \multicolumn{2}{|c|}{ MA } & \multicolumn{2}{|c|}{ PH D } \\
\hline & Male & Female & Male & Female \\
\hline Linguistics & 3 & 4 & 2 & \\
\hline Literature & 4 & 3 & & 2 \\
\hline $\begin{array}{c}\text { Translatio } \\
\mathbf{n}\end{array}$ & 3 & 4 & 2 & \\
\hline Total & & & 27 & \\
\hline
\end{tabular}

Table (2) indicates that the subjects are of the three specializations that allow their holders to teach English in the English or Translation departments, which will not be regarded as variables in data analysis. For the administration of the questionnaire, the twenty-seven subjects were given all the time needed for filling up the papers: some of them took three days as a minimum period; others took sixteen days as a maximum period. Papers of the questionnaire were submitted and gathered by the researcher himself. The researcher tried to give immediate chance of details or explanation to those needed.

The purpose of the present study is to get answers to the following questions:

1- Are teachers really aware of these SLLSs that their students adopt and use inside or outside their classroom? If this is true, this means that the subjects who are university- level teachers are able to identify the points of strength and weakness in their students' second language level. This means also that the subjects can reflect these fifty strategies to their students when they teach them in one way or another.

2- Which particular strategy university- level teachers identify that their students are well -aware of? In turn, this leads to know the opposite, i.e., which strategy is less aware of.

3- Which category of SLLSs is more problematic (or less acquainted/adopted/used by students)? This will be clear when "never" option is ticked by the twenty-seven subjects. This in turn leads to know which category of SLLSs is less problematic (or more acquainted/ adopted/ used by students).

4-Is there any difference in strategy awareness of students as far as the three specializations are compared: linguistics, translation, and literature?

\section{RESULTS AND DISCUSSION}

The following table shows the statistical analysis of each strategy depending on the subjects ticking and Likert Scale. This Scale is an ordered, one-dimensional scale from which respondents choose one option that best aligns with their view. All options usually have labels, although sometimes only a few are offered and the others are implied. A common form is an assertion, with which the person may agree or disagree to varying degrees. In scoring, numbers are usually assigned to each option (such as 1 to 3 ) since the options of this questionnaire are three. The Likert scale is also called the summative scale, as the result of a questionnaire is often achieved by summing numerical assignments to the responses given. The three-point scale was applied:

1 Never 
2 Sometimes

3 Always

The marks stated in front each option will help statistically, according to the application of the Likert scale, to account the weighted means for each strategy to show their means which will be compared to the standard mean which must be (2): ( 0-1) is low use. (1-2) medium use, and (2-3) high use .Table (3) shows in detail the strategy type, strategy number and the number of ticking for each one of the three options, then followed by their weighted means which is accounted according to the following equation:

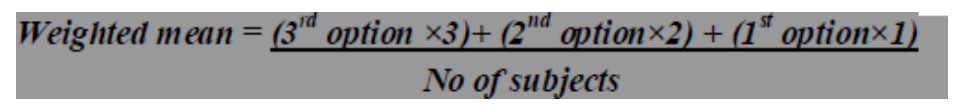

Thus, the weighted mean of Strategy 1 can be accounted as follows:

$$
\begin{gathered}
\text { Weighted mean }=\frac{(3 \times 3)+(2 \times 20)+(1 \times 4)}{27}=1.962>2(\text { standard mean }) \\
\text { TABLE }(3):
\end{gathered}
$$

\begin{tabular}{|c|c|c|c|c|c|c|c|c|c|c|c|}
\hline $\begin{array}{l}\text { STR } \\
\text { Type }\end{array}$ & $\begin{array}{l}\text { ST } \\
\text { No }\end{array}$ & Never & Sometimes & Always & $\begin{array}{l}\text { W } \\
\text { Mean }\end{array}$ & $\begin{array}{l}\text { STR } \\
\text { TYPE }\end{array}$ & $\begin{array}{l}\text { ST } \\
\text { No }\end{array}$ & Never & Sometimes & Always & $\begin{array}{l}\text { W } \\
\text { Mean }\end{array}$ \\
\hline \multirow{9}{*}{ 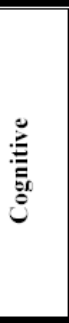 } & 1 & 4 & 20 & 3 & 1.962 & \multirow{4}{*}{$\frac{\bar{g}}{\frac{\tilde{g}}{2}}$} & 26 & 8 & 11 & 8 & 1.925 \\
\hline & 2 & 2 & 21 & 4 & 2.074 & & 27 & 7 & 11 & 9 & 2.074 \\
\hline & 3 & 7 & 18 & 2 & 1.814 & & 28 & 10 & 11 & 6 & 1.777 \\
\hline & 4 & 7 & 15 & 5 & 1.924 & & 29 & 5 & 11 & 11 & 2.222 \\
\hline & 5 & 13 & 12 & 2 & 1.592 & \multirow{9}{*}{ 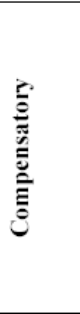 } & 30 & 9 & 13 & 5 & 1.851 \\
\hline & 6 & 19 & 7 & 1 & 1.333 & & 31 & 7 & 18 & 2 & 1.814 \\
\hline & 7 & 15 & 11 & 1 & 1.481 & & 32 & 5 & 10 & 12 & 2.259 \\
\hline & 8 & 4 & 20 & 3 & 1.962 & & 33 & 6 & 9 & 12 & 2.222 \\
\hline & 9 & 5 & 15 & 7 & 2.074 & & 34 & 8 & 15 & 4 & 1.581 \\
\hline \multirow{16}{*}{ 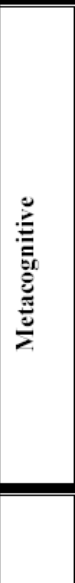 } & 10 & 6 & 12 & 9 & 2.111 & & 35 & 11 & 11 & 5 & 1.777 \\
\hline & 11 & 7 & 17 & 3 & 1.814 & & 36 & 7 & 16 & 4 & 1.888 \\
\hline & 12 & 10 & 10 & 7 & 1.888 & & 37 & 9 & 12 & 6 & 1.888 \\
\hline & 13 & 8 & 13 & 6 & 1.925 & & 38 & 6 & 10 & 11 & 2.185 \\
\hline & 14 & 7 & 13 & 7 & 2 & \multirow{6}{*}{ 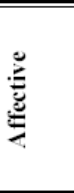 } & 39 & 8 & 10 & 9 & 2.037 \\
\hline & 15 & 5 & 15 & 7 & 2.074 & & 40 & 7 & 13 & 7 & 2 \\
\hline & 16 & 11 & 12 & 4 & 1.740 & & 41 & 11 & 8 & 8 & 1.888 \\
\hline & 17 & 10 & 10 & 7 & 1.888 & & 42 & 8 & 9 & 10 & 2.074 \\
\hline & \begin{tabular}{|l|}
18 \\
\end{tabular} & 9 & 12 & 6 & 1.888 & & 43 & 18 & 9 & --- & 1.333 \\
\hline & 19 & 8 & 10 & 9 & 2.037 & & 44 & 6 & 10 & 11 & 2.185 \\
\hline & 20 & 8 & 14 & 5 & 1.888 & \multirow{6}{*}{ 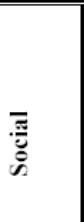 } & 45 & 4 & 8 & 15 & 2.037 \\
\hline & 21 & 9 & 13 & 5 & 1.851 & & 46 & 9 & 13 & 5 & 1.851 \\
\hline & 22 & 10 & 11 & 6 & 1.851 & & 47 & 6 & 10 & 11 & 2.185 \\
\hline & 23 & 10 & 11 & 6 & 1.851 & & 48 & 10 & 12 & 5 & 1.814 \\
\hline & 24 & 8 & 8 & 11 & 2.111 & & 49 & 4 & 15 & 8 & 2.148 \\
\hline & 25 & 6 & 11 & 10 & 2.148 & & 50 & 11 & 10 & 6 & 1.814 \\
\hline
\end{tabular}

THE FifTy STRATEGIES AND THEIR WeIGHTED MEANS

Statistically speaking, this table shows clearly these twenty strategies that are students are aware of. They are represented by shaded rows. Also, it can be concluded that arranging the fifty strategies according to their weighted means may help to draw a clear picture of students' awareness and use of these strategies. That is, strategies with weighted means (2) or more means they are more adopted and used by the subjects' students at least inside the classroom( or less problematic). And the opposite is correct, i.e., those strategies with weighted means less than (2) are less adopted and used by students (or more problematic). This picture is represented by the following line curve of these weighted means: 


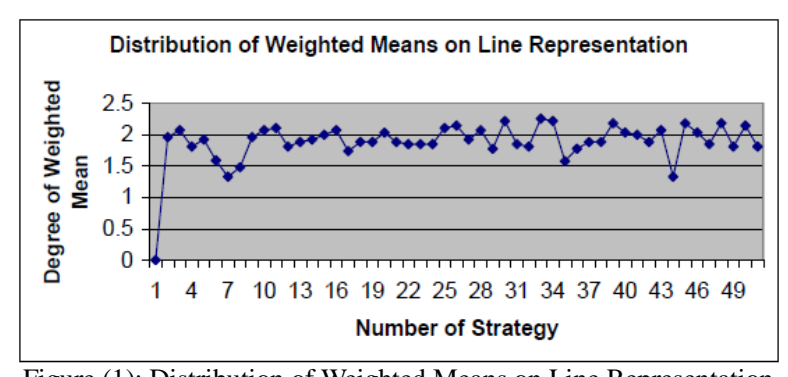

Figure (1): Distribution of Weighted Means on Line Representation

Fortunately, this indicates, as a conclusion, that teachers are well-aware of these SLLSs adopted and used by their students since they are able to identify, even relatively, which strategies are more usable and adoptable inside the classroom. In other words, are able to identify the points of strength in SLLSs ( those with shaded rows in the above table) and points of weakness ( the non-shaded rows). And due to the fact that SLLSs are teachable ( Lee \& Oxford,2008), focusing on these points of weakness is very important to have proficient learners(p.3-14). Table (4) below indicates the total performance of subjects to Oxford's six categories of strategies:

TABLE (4)

TOTAL PERFORMANCE OF SUBJECTS IN OXFORD’s SiX STRATEGIES

\begin{tabular}{|c|c|c|c|c|c|c|}
\hline \multirow{2}{*}{$\begin{array}{l}\text { Strategy } \\
\text { No }\end{array}$} & \multicolumn{2}{|c|}{ Never } & \multicolumn{2}{|c|}{ Sometimes } & \multicolumn{2}{|c|}{ Always } \\
\hline & $\overline{\text { No }}$ & $\%$ & $\overline{\text { No }}$ & $\%$ & $\overline{\text { No }}$ & $\%$ \\
\hline 1 & 76 & 31.2 & 139 & 57.2 & 28 & 11.6 \\
\hline 2 & 118 & 31.2 & 173 & 45.7 & 87 & 23.1 \\
\hline 3 & 44 & 27.3 & 63 & 38.8 & 55 & 33.9 \\
\hline 4 & 68 & 28 & 114 & 46.9 & 61 & 25.1 \\
\hline 5 & 58 & 35.8 & 59 & 36.4 & 45 & 27.8 \\
\hline 6 & 44 & 27.3 & 68 & 41.9 & 50 & 30.8 \\
\hline \multirow[t]{2}{*}{ Total } & 408 & 30.2 & 616 & 45.6 & 326 & 24.2 \\
\hline & \multicolumn{6}{|c|}{1350} \\
\hline
\end{tabular}

This table can be represented by the following histogram.

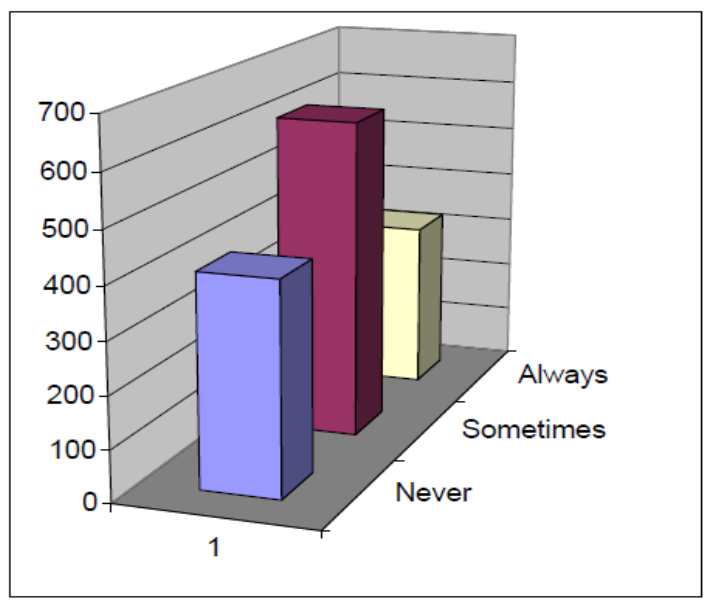

Figure (2): Histogram of Total Responses

Statistically speaking, the numbers in Table (4) above are not sufficient to conclude which type of strategy is more adoptable than others. Thus, after consulting specialists in statistics another statistical measure is used, namely, Expected Opportunity Loss (or EOL) as detailed in Al-fahdi (1994).This measure is used in situations where exact decision could not be obtained as in measuring or identifying the exact strategies that students adopt or use (p.83ff). Instead, the maximum percentage of use will be regarded as the less EOL, which will be used in turn to measure other percentages of use. This is done in the following way:

1- Obtaining maximum EOL by the following equation

$\mathrm{L}^{\prime} \mathrm{i}=\operatorname{Maxj} \times \mathrm{Lij}$

$\mathrm{i}=1,2$,

$\mathrm{j}=1,2, \ldots \ldots \ldots \ldots, n$

2- Selecting Mini EOL to be the optimal alternative for minimum expected opportunity lost. Then this minimum can 
then be used to find EOL for others by the following equation:

$$
\begin{array}{r}
\text { EOL (ai })=\sum_{\mathrm{J}=1}^{\mathrm{m}} \mathrm{Lij} \cdot \mathrm{Pj} \\
\mathrm{Pj}=\mathrm{P}(\Phi=\Phi \mathrm{j}), \quad \mathrm{j}=1,2, \ldots
\end{array}
$$

By applying these equations the following table is obtained:

Option $=\mathrm{i}$

Strategy $=\mathrm{j}$

$\mathrm{P}(\mathrm{i} 1)=\mathrm{P}(\mathrm{i} 2)=\mathrm{P}(\mathrm{i} 3)=1 / 3$

TABLE (5):

EOL FOR THE SIX TYPES OF STRATEGIES

\begin{tabular}{||c||c|c|c|c|c|c|}
\hline Strategy & 1 & 2 & 3 & 4 & 5 & 6 \\
Option & $\mathrm{j} 1$ & $\mathrm{j} 2$ & $\mathrm{j} 3$ & $\mathrm{j} 4$ & $\mathrm{j} 5$ & $\mathrm{j} 6$ \\
\hline $\begin{array}{c}\text { Never } \\
\mathrm{i} 1\end{array}$ & 42 & 0 & 74 & 50 & 60 & 74 \\
\hline $\begin{array}{c}\text { Sometimes } \\
\mathrm{i} 2\end{array}$ & 34 & 0 & 110 & 59 & 114 & 105 \\
\hline $\begin{array}{c}\text { Always } \\
\text { i3 }\end{array}$ & 59 & 0 & 32 & 26 & 42 & 37 \\
\hline
\end{tabular}

$\operatorname{EOL}(1)=(1 / 3 \times 42)+(1 / 3 \times 34)+(1 / 3 \times 59)=45$

$\operatorname{EOL}(2)=(1 / 3 \times 0)+(1 / 3 \times 0)+(1 / 3 \times 0)=0$

$\operatorname{EOL}(3)=(1 / 3 \times 74)+(1 / 3 \times 110)+(1 / 3 \times 32)=72$

$\operatorname{EOL}(4)=(1 / 3 \times 50)+(1 / 3 \times 59)+(1 / 3 \times 26)=45$

$\operatorname{EOL}(5)=(1 / 3 \times 60)+(1 / 3 \times 114)+(1 / 3 \times 42)=72$

$\operatorname{EOL}(6)=(1 / 3 \times 74)+(1 / 3 \times 105)+(1 / 3 \times 37)=72$

Thus, the second type of strategies, i.e., Meta - cognitive strategies, is the most adoptable or used since it gives the less EOL. As a conclusion, these six types of strategies can be arranged as follows:

1- Meta-cognitive strategies

2- Cognitive and Compensatory strategies

3- Memory-related, Affective and Social strategies

Consequently, the above discussion gives answers to the first three questions of the questionnaire. The following is a statistical treatment for obtaining an answer to the fourth question.

TABLE (6):

\begin{tabular}{|c|c|c|c|c|c|c|c|c|c|c|c|c|}
\hline 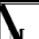 & \multicolumn{4}{|c|}{ Linguistics } & \multicolumn{4}{|c|}{ Literature } & \multicolumn{4}{|c|}{ Translation } \\
\hline $\mathrm{S}$ & $\mathrm{N}$ & $\mathrm{S}$ & $\bar{A}$ & WM & $\bar{N}$ & $\mathrm{~s}$ & $\bar{A}$ & WM & $\mathrm{N}$ & $\mathrm{s}$ & $\bar{A}$ & WM \\
\hline 1 & 16 & 55 & 10 & 1.95 & 34 & 34 & 13 & 1.74 & 26 & $\overline{50}$ & 5 & 1.74 \\
\hline 2 & 28 & 62 & 36 & 2.06 & 71 & 24 & 31 & 1.68 & 19 & 87 & 20 & 2.00 \\
\hline 3 & 12 & 23 & 19 & 2.12 & 28 & 7 & 19 & 1.83 & 4 & 33 & 17 & 2.24 \\
\hline 4 & 23 & 46 & 12 & 1.86 & 37 & 13 & 31 & 1.92 & 8 & 55 & 18 & 2.12 \\
\hline 5 & 19 & 25 & 10 & 1.83 & 24 & -- & 30 & 2.11 & 15 & 34 & 5 & 1.81 \\
\hline 6 & 10 & 38 & 6 & 1.11 & 24 & --- & 3 & 2.11 & 10 & 30 & 14 & 2.07 \\
\hline \multirow{2}{*}{$\overline{\underline{\pi}}$} & 108 & 249 & 93 & 1.96 & 218 & 78 & 154 & 1.85 & 82 & 293 & 75 & 1.98 \\
\hline & \multicolumn{4}{|c|}{450} & \multicolumn{4}{|c|}{450} & \multicolumn{4}{|c|}{450} \\
\hline
\end{tabular}

TEACHERS' AWARENESS AND THEIR SPECIALIZATION MAJOR

By adopting the above-used EOL measure, the following results are revealed:

Strategy $=\mathrm{S}$

Major fields of knowledge (Linguistics , ....) $=\mathrm{T}$

$\mathrm{P}(\mathrm{S} 1)=\mathrm{P}(\mathrm{S} 2)=\ldots \ldots . .=\mathrm{P}(\mathrm{S} 6)=1 / 6$ 
TABLE (7):

EOL FOR TEACHERS' MAJOR FIELDS OF KNOWLEDGE

\begin{tabular}{|c|c|c|c|c|c|c|c|c|c|}
\hline $\mathrm{T}$ & \multicolumn{3}{|c|}{ T1 (Linguistics) } & \multicolumn{3}{|c|}{ T2(Literature) } & \multicolumn{3}{|c|}{ T3 (Translation) } \\
\hline S & $\mathrm{N}$ & $\mathrm{S}$ & $\mathrm{A}$ & $\mathrm{N}$ & $\mathrm{S}$ & $\mathrm{A}$ & $\mathrm{N}$ & $\mathrm{S}$ & $\mathrm{A}$ \\
\hline 1 & 12 & 7 & 26 & 37 & 0 & 18 & 0 & 37 & 15 \\
\hline 2 & 0 & 0 & 0 & 0 & 10 & 0 & 7 & 0 & 0 \\
\hline 3 & 16 & 39 & 17 & 43 & 27 & 12 & 22 & 44 & 3 \\
\hline 4 & 5 & 16 & 24 & 34 & 24 & 0 & 18 & 22 & 2 \\
\hline 5 & 9 & 37 & 26 & 47 & 34 & 1 & 11 & 43 & 15 \\
\hline 6 & 18 & 24 & 20 & 47 & 34 & 28 & 16 & 47 & 6 \\
\hline
\end{tabular}

$\operatorname{EOL~T} 1(\mathrm{~N})=(1 / 6 \times 12)+(1 / 6 \times 0)+(1 / 6 \times 16)+(1 / 6 \times 5)+(1 / 6 \times 9)+(1 / 6 \times 18)=10$

EOL T1 $(S)=(1 / 6 \times 7)+(1 / 6 \times 0)+(1 / 6 \times 39)+(1 / 6 \times 16)+(1 / 6 \times 37)+(1 / 6 \times 24)=20.5$

EOL T $1(\mathrm{~A})=(1 / 6 \times 26)+(1 / 6 \times 0)+(1 / 6 \times 17)+(1 / 6 \times 24)+(1 / 6 \times 26)+(1 / 6 \times 20)=18.83$

ELO T2 $(\mathrm{N})=34.67$

ELO T2 $(S)=21.5$

ELO T2 $(\mathrm{A})=9.83$

ELO T $3(\mathrm{~N})=12.33$

ELO T3 $(\mathrm{S})=32.17$

ELO T3(NA) $=6.83$

These results reflect, on the one hand, how much these majors are different in their students' strategies; strategies that are obtained mainly from their teachers. This means those teachers reflect different types of strategies in their classrooms. Also, these reflect the gap will be seen among students as far as learning strategies are concerned, on the other hand. The less EOL are EOL T3 (A), EOL T1 (N), and EOL T1 (S). This indicates relatively the influence of linguistic aspects or issues on this respect. So, students in these three majors are users and adopters of different strategies. And this is the answer of the questionnaire's fourth question. Specifically, the following points derived from Table (6) above can support this conclusion:

i- There is a kind of approximation in selecting options between Linguistics and Translation, especially in 'sometimes' and 'always' options for cognitive, meta-cognitive strategy.

ii-Literature are more decisive in their selection, especially for affective and social strategies. No instance is registered for 'sometimes' in these strategies. Whereas the other two options are similar for both types of strategies. This can be justified unfortunately of being unaware of the distinction between these two types of strategies.

iii- Weighted mean reaches its high point in compensatory strategies for both Linguistics and Translation whereas in affective strategies for Literature.

iv- Literature are the less in selecting 'sometimes' for all types of strategies compared with Linguistics and Translation.

$\mathrm{v}$ - "Always" is resisted as the highest selection for all the three majors in meta-cognitive strategies compared with other types of strategies. This in turn supports the above- stated conclusion that meta-cognitive strategies are more usable and adoptable inside classroom for Iraqi EFL.

vi- The less number of "always' is registered in social, cognitive and affective, and compensatory strategies for Linguistics, Translation, and Literature, respectively.

vii- By ordering the different types of strategies according to their weighted means from the more to the less, the following orders can be revealed:

\begin{tabular}{lll} 
Linguistics & $\underline{\text { Translation }}$ & $\underline{\text { Literature }}$ \\
\hline Compensatory & Compensatory & Affective \\
Meta-cognitive & Memory-related & Compry-related \\
Cognitive & Social & Cognitive \\
Memory-related & Meta-cognitive & Meta-cognitive \\
Affective & Affective & Social \\
Social & Cognitive & .
\end{tabular}

These results are indicators of the different techniques used by teachers of these majors inside the classroom. This can be justified positively and negatively. From a positive viewpoint, students adopted and used these strategies that help them in their studies. For example, students of literature and translation need more memory-related strategies than in studying linguistics. This is proved its validity in the above order of strategies where memory-related strategies are ordered the second in Translation and Literature compared with the fourth order in Linguistics. Negatively, students in their study have focused on some strategies which may affect their learning process in general (see Beckma, 2002).

\section{CONCLusions}

The main findings of the present study are: 
1- Iraqi university-level teachers are aware of these strategies adopted and used by their students since the results of the questionnaire have indicated that some strategies, but not all, are more usable and adoptable by their students. This point will be more illustrative if a large sample is used.

2- If 1 is TRUE, teachers can raise their students' awareness and use of these important strategies by focusing on these less-used strategies. The three majors can apply them inside their classroom since their courses are with social, affective, and cognitive orientations. That is, strategy-based instruction is advisable since more successful learners have better and more meta-cognitive awareness.

3- Indirectly, the statistical analysis indicated that the individual differences among our students are considerable since less number of strategies is identified as points of strength. As believed by many researches like Oxford (1990, 2001, and 2008), the learning strategies of good language learners, once identified and successfully taught to less proficient learners could have considerable effects of facilitating the development of SL skills.

4- Meta-cognitive strategies are used and adopted by Iraqi EFL more than other types of strategies; therefore, they are less problematic than other types of strategies while Affective strategies are found to be the more problematic category.

5- The profile of L2LSs in Iraq needs more attention since majority of strategies are reflected as unaware.

\section{APPENDIX}

Strategy Inventory for Language Learning (SILL)

This form of the strategy inventory for language learning (SILL) is for students of English as a second or foreign language. You will find statements about learning English. Please read each statement and write the response (1, 2, 3, 4, or 5) that tells HOW TRUE THE STATEMENT IS.

1. Never or almost never true of me

2. Usually not true of me

3. Somewhat true of me

4. Usually true of me

5. Always or almost always true of me

Answer in terms of how well the statement describes you. Do not answer how you think you should be, or what other people do. There are no right or wrong answers to these statements. This questionnaire usually takes about 20-30 minutes to complete. If you have any questions, let the teacher know immediately.

\section{Part A}

1. I think of relationships between what I already know and new things I learn in English.

2. I use new English words in a sentence so I can remember them.

3. I connect the sound of a new English word and an image or picture of the word to help me remember the word.

4. I remember a new English word by making a mental picture of a situation in which the word might be used.

5. I use rhymes to remember new English words.

6. I use flashcards to remember new English words.

7. I physically act out new English words.

8. I review English lessons often.

9. I remember new English words or phrases by remembering their location on the page, on the board, or on a street sign.

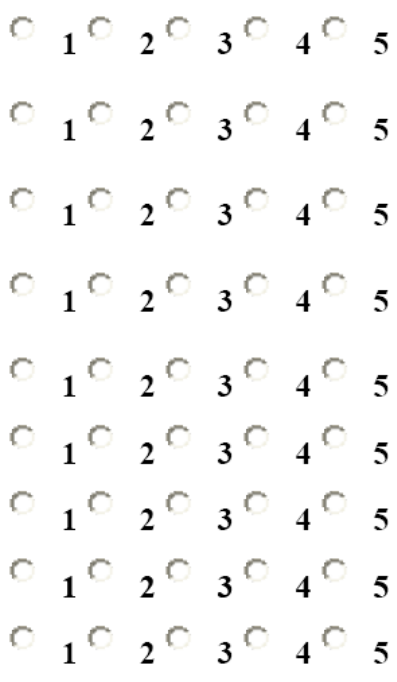

\section{Part B}

10. I say or write new English words several times.

11. I try to talk like native English speakers.

12. I practice the sounds of English.

13. I use the English words I know in different ways.

14. I start conversations in English.

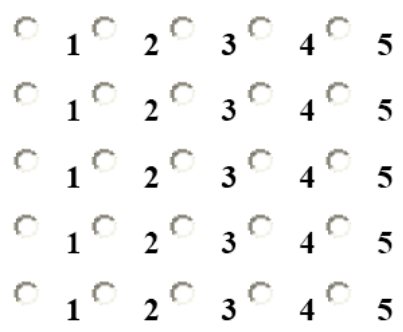




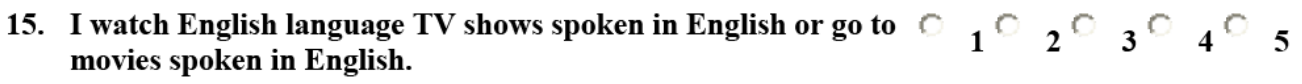

16. I read for pleasure in English.

17. I write notes, messages, letters, or reports in English.

${ }_{1} \curvearrowright_{2} r_{3} r_{4} \curvearrowright 5$

18. I first skim an English passage (read over the passage quickly) then go back and read carefully.

19. I look for words in my own language that are similar to new words in English.

20. I try to find patterns in English.

21. I find the meaning of an English word by dividing it into parts $\curvearrowright{ }_{1} \curvearrowright{ }_{2} \curvearrowright{ }_{3} \curvearrowright{ }_{4} \curvearrowright 5$ that I understand.

22. I try not to translate word for word.

23. I make summaries of information that $I$ hear or read in English.

${ }_{1} r_{2} r_{4} r_{5}$

${ }_{1} \curvearrowright 2_{3}{ }_{3}{ }_{4}{ }_{5}$

${ }_{1} r_{2}{ }_{3} r_{4} \curvearrowright 5$

${ }_{1} \curvearrowright{ }_{2} \curvearrowright{ }_{4} \curvearrowright 5$

${ }_{1} r_{2}{ }_{3} r_{4}{ }_{5}$

${ }_{1} r_{2}{ }_{3} r_{4}{ }_{5}$

\section{Part C}

24. To understand unfamiliar English words, I make guesses.

${ }_{1} r_{2}{ }_{3} r_{4}{ }_{5}$

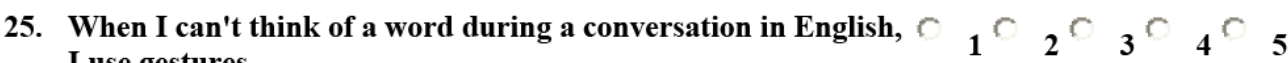
I use gestures.

26. I make up new words if I do not know the right ones in English.

27. I read English without looking up every new word.

28. I try to guess what the other person will say next in English.

${ }_{1}{ }_{2} \curvearrowright 3_{4} \curvearrowright 5$

○ ${ }_{1}{ }_{2}{ }_{3}{ }_{4} \curvearrowright 5$

$r_{1} r_{2}{ }_{3} r_{4}{ }_{5}$

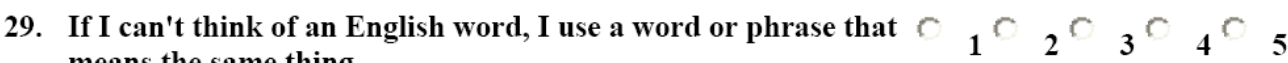
means the same thing.

\section{Part D}

30. I try to find as many ways as I can to use my English.

${ }_{1} r_{2}{ }_{3} r_{4}{ }_{5}$

31. I notice my English mistakes and use that information to help me do better.

32. I pay attention when someone is speaking English.

33. I try to find out how to be a better learner of English.

${ }_{1} r_{2}{ }_{3}{ }_{4}{ }_{5}$

34. I plan my schedule so I will have enough time to study English.

35. I look for people I can talk to in English.

${ }_{1} \curvearrowright{ }_{2} \curvearrowright 3_{4} \curvearrowright 5$

${ }_{1} r_{2}{ }_{3} r_{4}{ }_{5}$

36. I look for opportunities to read as much as possible in English.

${ }_{1} \curvearrowright{ }_{2} \curvearrowright 3_{4} \curvearrowright 5$

36. I look for opportunities to read as much as possible in English.

${ }_{1} \curvearrowright{ }_{2} \curvearrowright{ }_{4} \curvearrowright 5$

37. I have clear goals for improving my English skills.

38. I think about my progress in learning English.

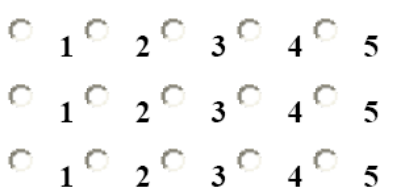

Part E

39. I try to relax whenever I feel afraid of using English.

${ }_{1} \curvearrowright{ }_{2}{ }_{3} r_{4}{ }_{5}$

40. I encourage myself to speak English even when I am afraid of making a mistake.

41. I give myself a reward or treat when I do well in English.

42. I notice if I am tense or nervous when I am studying or using English.

43. I write down my feelings in a language learning dairy.

44. I talk to someone else about how I feel when I am learning English.

$$
\begin{aligned}
& { }_{1} \curvearrowright{ }_{2}{ }_{3}{ }_{4} \curvearrowright 5 \\
& \curvearrowright{ }_{1} \curvearrowright{ }_{2} \curvearrowright{ }_{4} \curvearrowright 5 \\
& { }_{1} \curvearrowright{ }_{2} \curvearrowright{ }_{3}{ }_{4}{ }_{5} \\
& { }_{1} \curvearrowright 2_{3}{ }_{4} \curvearrowright 5 \\
& { }_{1} \curvearrowright{ }_{2}{ }_{3}{ }_{4}{ }_{5}
\end{aligned}
$$




\section{Part F}

\begin{tabular}{|c|c|c|c|c|c|c|}
\hline 45. & $\begin{array}{l}\text { If I do not understand something in English, I ask the other } \\
\text { person to slow down or say it again. }\end{array}$ & & 1 & $2^{r}$ & $3^{r}$ & $4 r$ \\
\hline 46. & I ask English speakers to correct me when I talk. & $c$ & $1 r$ & $2^{r}$ & $3^{r}$ & $4^{r}$ \\
\hline 47. & I practice English with other students. & $r$ & $1 \curvearrowright$ & $2^{r}$ & $3^{r}$ & $4^{r}$ \\
\hline 48. & I ask for help from English speakers. & $c$ & 1 & $2^{r}$ & $3^{r}$ & $4^{r}$ \\
\hline 49. & I ask questions in English. & $\mathrm{c}$ & $1 r$ & $2 r$ & $3^{r}$ & $4^{r}$ \\
\hline 50. & I try to learn about the culture of English speakers. & $r$ & $1 r$ & $2 r$ & $3^{r}$ & $4 r$ \\
\hline
\end{tabular}

\section{REFERENCES}

[1] Al-Fahdi, Q. (1994). Decisions. Mousl: Mousl University Press.

[2] Beckman,P.(2002). "Strategy Instruction". Retrieved, February, 12, 2009 from the web site: http://eric.hoagiesgifted.org.

[3] Brown, H., D. (2000). Principles of Language Teaching and Learning (5th ed.). White Plains, New York: Prentice-Hall.

[4] Brown, H., D. (2001). Teaching by Principles: An Interactive Approach to Language Pedagogy (2nd ed.). London: Longman.

[5] Canale, M., \& Swain, M. (1994). "Theoretical Bases of Communicative Approaches to Second Language Teaching and Testing". In Applied Linguistics, 1, 1, Pp. 1-47.

[6] Celce-Murcia, M. (ed.) Teaching English as a Second or Foreign Language (3rd ed.). USA: Heinle \& Heinle.

[7] Cook,V. (2001). Second Language Learning and Language Teaching. London: Arnold.

[8] Ellis, R. (1994). The Study of Second Language Acquisition. Oxford: Oxford University Press.

[9] Ellis, R. (2005). Analysing Learner Language. Oxford: Oxford University Press.

[10] Faerch, C., \& G. Kasper. (1983). Strategies in Interlanguage Communication. London: Longman.

[11] Lee, K. R. \& Oxford, R. (2008). "Understanding EFL Learners' Strategy Use and Strategy Awareness". In The Asian EFL Journal, Vol.10, issue no. 1, Pp.1-17.

[12] Lessard-Clouston, M. (1997). "Language Learning Strategies: An Overview for Teachers". In TESL Journal, 3, 12, pp. 3-8.

[13] Mayer, R. (1988). "Learning Strategies: An Overview". In Weinstein, C., Goetz, \& P. Alexander (Eds.), Learning and Study Strategies: Issues in Assessment, Instruction, and Evaluation. New York: Academic Press. pp. 11-22.

[14] Naiman, N., Frohlich, M., Stern, H., \& Todesco, A. (1978). "The Good Language Learner". Research in Education, Series 7. Toronto: OISE Press.

[15] O’Malley, J. M., Chamot, A. U., Stewner- Manzanares, G. Russo, R. (1985). "Learning Strategy Application with Students of English as a Second Language". In TESOL Quarterly, 19, Pp. 557-584.

[16] O’Malley, J. M., \& Chamot, A. (1990). Learning Strategies in Second Language Acquisition. Cambridge: Cambridge University Press.

[17] Oxford, R. L. (1990). Language Learning Strategies: What Every Teacher Should Know. Boston, MA: Heinle \& Heinle.

[18] Oxford, R. L. (1993). "Instructional Implications of Gender Differences in Language Learning Styles and Strategies" .In Applied Language Learning, 4, pp. 65-94.

[19] Oxford, R. L. (1994). "Language Learning Strategies: An Update". Retrieved, February 12, 2009 from the Web site: http://www.cal.org/resources/digest/oxford01.html.

[20] Oxford, R. L. (2001). "Language learning styles and strategies". In M. Celece-Murcia (Ed.), Teaching English as a Second or Foreign Language (3ed ed.). Boston: Heinle \& Heinle. Thompson International, pp. 359-366.

[21] Reid, J. (1995). Learning Styles in the ESL/EFL Classroom Boston: Heinle \& Heinle.

[22] Rubin, J. (1987). Learner Strategies: Theoretical Assumptions, Research History and Typology. Englewood Cliffs, NJ: Prentice Hall.

[23] Skehan, P. (1989). "Language Learning Strategies. Individual Differences" in Second Language Learning. London: Edward Arnold.Pp. 73-99.

[24] Stern, H. H., (1992). Issues and Options in Language Teaching. Oxford: Oxford University Press.

[25] Tarone, E. (1983)." Some Thoughts on the Notion of Communication Strategy". In C. Faerch \& G. Kasper (Eds.), Strategies in Interlanguage Communication. London: Longman.Pp. 61-74.

[26] Vann, R., \& Abraham, R. (1990). "Strategies of Unsuccessful Language Learners". In TESOL Quarterly, 24, 2, Pp. 177-198.

[27] Weinstein, C, \&Mayer, R. (1986). "The Teaching of Learning Strategies". In M.C. Wittrock (Ed.), Handbook of Research on Teaching, (3rd.). New York: Macmillan. Pp.315-327.

[28] Wenden, A., \& Rubin, J. (1987). Learner Strategies in Language Learning (Eds.). Englewood Cliffs, NJ: Prentice Hall.

[29] Wittrock M.C. (ed.), Handbook of Research on Teaching, (3rd.). New York: Macmillan.

[30] Yang, M. (2007). "Language Learning Strategies for Junior College Students in Taiwan: Investigating Ethnicity and Proficiency". In The Asian EFL Journal, Vol. 9, No. 2, Pp. 35-57. 


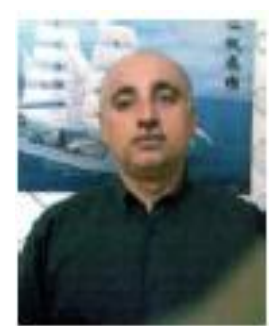

Ahmed Qadoury Abed was born in Baghdad 1973. M.A. in Linguistics from Baghdad University, College of Arts Department of English (1996).B.A. English Language and Linguistics from Al-Mustansiriyah University, College of Arts, Department of English (1994). Major fields of study include General Linguistics, Second Language Acquisition, and Applied Pragmatics.

$\mathrm{He}$ is working a teaching staff in Al-Mustansiriyah University, College of Arts, Department of Translation (2008- ). He worked in Libya for five years as a teacher staff and then as a chairman of The English Department in Qeminins Higher Institute of Teachers Training, (1998-2003). He worked as a teacher staff in The English Department, College of Education, Wassit University for four years (2004-2006). He published more than eight papers inside Iraq and one in The Modern Journal of Applied Linguistics, 2 (1), 2010. (India) "Universal Grammar and Second Language Learners: The Case of Pro-drop arameter". 